Л. О. Березко, С. Є. Соколов*

Національний університет “Львівська політехніка", кафедра електронних обчислювальних машин

*кафедра теоретичної радіотехніки та радіовимірювання

\title{
ОСОБЛИВОСТІ БІОТЕХНІЧНИХ КОМПОНЕНТІВ КІБЕРФІЗИЧНИХ СИСТЕМ
}

(С Березко Л. О.,Соколов С. С., 2016

Синтезовано узагальнені структури біомедичних електроімпедансних біотехнічних систем як компонентів кіберфізичних систем. Запропоновані методологічні рекомендації розвитку електроімпедансної апаратури.

Ключові слова: біомедичний електроімпеданс, біотехнічні системи, кіберфізичні системи.

\section{FEATURES OF BIOTECHNICAL PART CYBER-PHYSICAL SYSTEMS}

(C) Berezko L. A., Sokolov S. E., 2016

The main structures of biomedical electroimpedance biotechnical systems as part cyberphysical systems were synthesized. The methodological recommendations on the electoimpedance apparatus development process were made.

Key words: biomedical electroimpedance, biotechnical systems, cyber-physical systems.

\section{Вступ}

Сьогодні активно розвивається концепція створення кіберфізичних систем (КФС) для різноманітних сфер людської діяльності. КФС розглядаються як інтелектуальні системи, в яких інтегровано фізичні об'єкти, зовнішні пристрої, процесори, мережне обладнання. Основна мета створення КФС - контроль за поведінкою фізичних об'єктів як компонентів таких систем у реальному масштабі часу. Це системи, в яких відбувається взаємодія кібернетичних засобів (вимірювальних, обчислювальних, комунікаційних, керуючих, виконавчих) з фізичними процесами у довільних об' єктах $[15,16]$.

Перспективним є поширення концепції КФС на біомедичну галузь. У таких КФС фізичні об’ єкти це біооб'єкти (БО): від найпростіших до людини включно. Моніторинг поведінки БО кібернетичними методами, автоматичне отримання їх параметрів і характеристик у реальному часі забезпечують надійнішу взаємодію з БО. Зауважимо, що специфіка використання та фізичні ( біофізичні) особливості БО визначають особливості проектування та розроблення відповідних КФС.

Поширена концепція біотехнічних систем (БТС) [10-13], які містять необхідні прилади та засоби досліджень, а також сам БО, дає змогу розглядати БТС як автономний вимірювальнообчислювальний компонент КФС, розташований у структурі КФС між фізичним світом та комунікаційним середовищем.

Відповідно до багаторівневої базової платформи КФС поведінка ії компонентів на будь-якому рівні повинна бути надійною та передбачуваною. Якщо ця вимога повністю не виконується, то засоби наступного (вищого рівня) повинні компенсувати ці недоліки. БТС як компонент КФС містить вбудовані комп’ютерні засоби, які беруть на себе функції локального керування, попередньої обробки отриманих даних, подання їх у вигляді, необхідному для передавання та сприйняття верхніми рівнями КФС. Алгоритми регулювання інформаційних потоків у комуніка- 
ційному середовищі між БО та користувачами КФС забезпечують функціонування в режимі реального часу при моніторингу БО [16].

Незважаючи на значні успіхи світового електронного біомедичного приладобудування та створення БТС різного призначення, представлення БТС як компонента КФС надає нові широкі можливості.

Розвиток біології і медицини диктують необхідність пошуку інструментальних, об'єктивних засобів взаємодії з БО. Зауважимо, що під час модернізації, вдосконалення існуючих БТС оновлюється елементна база, переглядаються схемотехнічні розв'язки та програмне забезпечення, але принципи функціонування та параметри давачів первинної інформації принципово не змінюються. Зокрема це стосується БТС, які використовують біоелектроімпедансний метод при дослідженні БО. Проектування БТС як компонента КФС, базовою основою якої є біомедична електроімпедансометрія [1-4,5,6], має свої особливості і представляє суттєвий інтерес.

\section{Аналіз публікацій}

Представлення електронної техніки біомедичного призначення як БТС доволі поширено. Це відображено у публікаціях, що пов'язані з розробленням комплексних систем електромагнітотерапії [7], давачів для пульсової діагностики [8]. Розглянуті можливості синтезу БТС для штучного заміщення органів та функцій організму людини [9]. У роботах [10-13] були зроблені перші кроки у напрямку аналізу особливостей проектування біомедичноі електроімпедансної апаратури (БМЕА) як БТС.

Було показано: БМЕА у загальному вигляді може бути представлена однією з трьох структур БТС. Перша структура визначає інформативні біофізичні параметри. Друга структура дозволяє перетворити виміряне значення біофізичного параметра на фізіологічну характеристику БО. Третя структура розв'язує задачі перших двох при зовнішньому впливі на БО.

Крім загальнообов'язкових даних, що доводять доцільність розробки, ії верифікації, а також аналізу переваг та можливих недоліків порівняно з аналогами, біомедична техніка, що побудована за будь-якою структурою, повинна відповідати умовам, специфічним виключно для неї.

\section{Мета роботи}

Аналіз специфіки проектування БМЕА як цілісної БТС та як компонента КФС.

\section{Результати досліджень}

На рис. 1 зображено узагальнені структури БТС отримання діагностичної інформації методом електричної імпедансометрії.

Головною особливістю БМЕА $є$ взаємодія технічного пристрою вимірювання з БО. На кордоні “електрод - БО” виникає складне явище, що отримало назву поляризації. Похибка вимірювання, що при цьому утворюється, залежить від режиму вимірювання та матеріалу електродів. Тому для всіх структур БТС при використанні методу біоелектроімпедансометрії принципово важливо вибрати частоту та щільність вимірювання струму, а також конструкцію електродів та системи їх підключення (уніполярне, біполярне або тетраполярне).

Випадковий характер поляризаційної похибки потребує експериментального вивчення “поведінки" електродів у реальних умовах контакту з БО. Насамперед це стосується стабільності повторення результатів вимірювання та їх дрейфу.

Складність метрології БМЕА полягає у принциповій неможливості вибору взірцевого БО. Оцінити похибку вимірювання в такому випадку можна виключно моделюванням БО.

Розглянуті особливості є головними при проектуванні БМЕА у першій структурі БТС (рис. 1. $a$ ).

Отже, під час проектування серійної апаратури медичного призначення розробникам доводиться переводити значення БЕІ у ФХ. Для цього типу структури БТС (рис. $1, \sigma)$ справедливо все, що стосується попередньо розглянутої. Крім того, до неї додано два нові елементи: ФХ і перетворювач П з характеристикою перетворення

$$
\Phi X=\mathrm{F}(\mathrm{BEI}) \text {. }
$$

Прикладом другого типу структури БТС (рис. 1, б) є розроблений прилад, що визначає гематокритне число за визначеним значенням електричного імпедансу крові. 


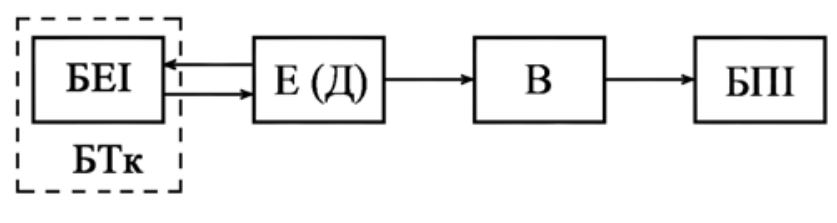

$a$

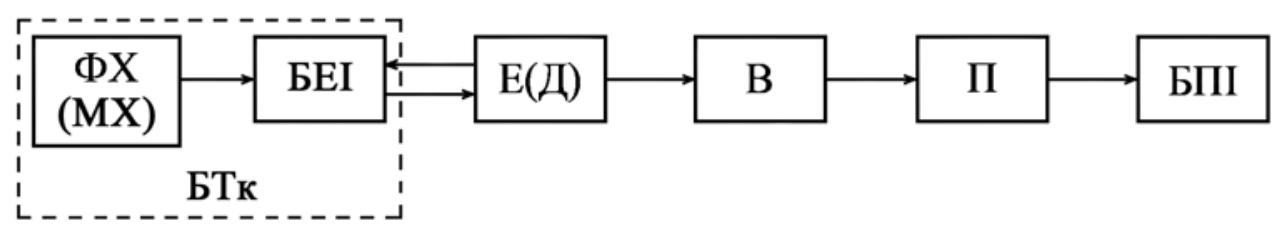

$\sigma$

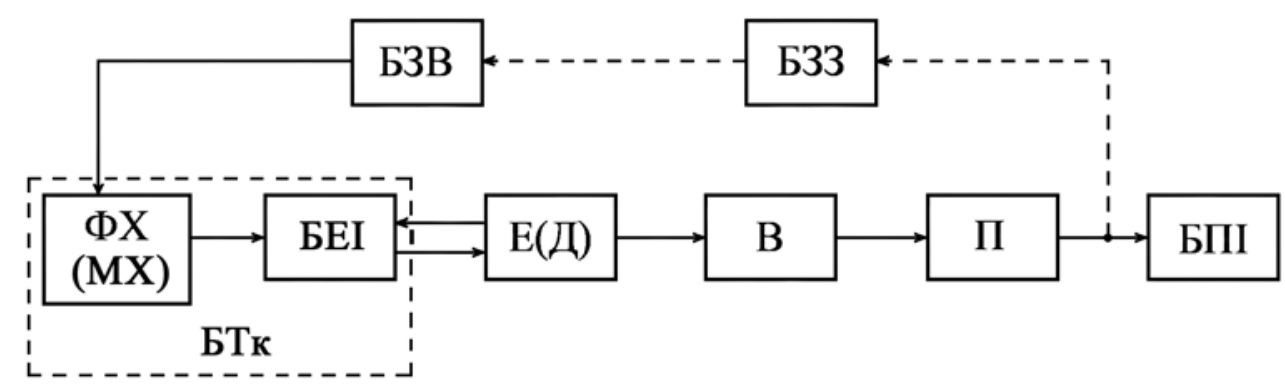

B

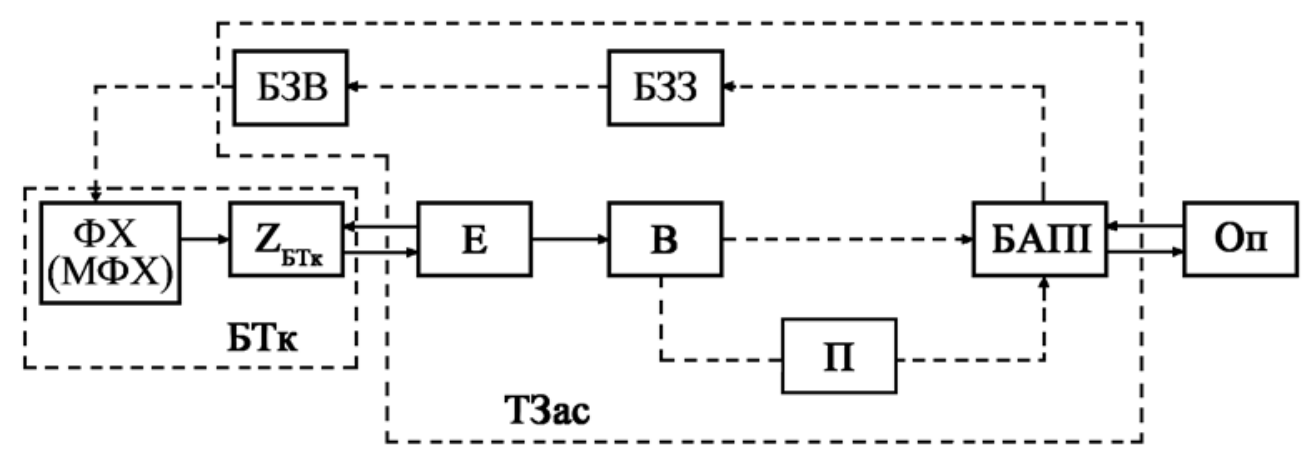

2

Рис. 1. Основні узагальнені структури БТС отримання інформації методом електричної імпедансометріі:

БEI - біоелектричний імпеданс; $Ф X$ - фізіологічна характеристика;

$M X$-морфологічна характеристика; БТк - біологічна тканина; $E$-електроди;

Д - давач; В - вимірювач електричного імпедансу; П-перетворювач; БПІ - блок представлення інформації; БЗВ - блок зовнішнього виливу;

Б33 - блок зворотного зв'язку; $Z_{\text {Бтк }}$-електричний імпеданс біологічної тканини;

БАПІ - блок аналізу та представлення інформаиї̈; On - оператор

Гематокритне число крові $\mathrm{Ht}$ - співвідношення об’ єму формених елементів (клітин) та всього об'єму крові - є одним 3 найважливіших показників крові. Його використовують під час розрахунків головних параметрів кровоносної системи, оцінювання крововтрати, контролю інфузійної терапії та інше.

Відомі дослідження, які підтверджують достатньо тісний зв'язок електричного імпеданса крові $Z_{\text {кр }}$ із значенням Ht. Але дані авторів не збігаються в характері цього зв'язку. Дехто вказує, що 
він має нелінійний характер. Наприклад, висновок широких експериментальних досліджень на різних типах тварин, викладений у [3], описується виразом:

$$
\mathrm{Z}_{\mathrm{\kappa p}}=\mathrm{A}+\mathrm{B} \cdot \mathrm{Ht}
$$

де $\mathrm{Z}_{\text {кр }}$ - електроімпеданс крові; A, B - коефіцієнти, які визначають вік і стать пацієнтів.

Коефіцієнт кореляції між даними, що отримані електричним та центрифугічним методами, в наших дослідженнях знаходився у межах $0,88 \div 0,96$.

Випробування показали переваги електроімпедансного метода для визначення $\mathrm{Ht}$ в експериментальних умовах, наприклад, у медицині катастроф.

3 використанням зовнішнього впливу на досліджуваний фізіологічний процес з метою стимуляції його прояву підключають блок зовнішнього впливу (БЗВ) (рис. 1, в). Прикладом такої структури є апарат для визначення тканинного кліренсу рідин та газів [13].

3 використанням зовнішньої дії як терапевтичної до структури БТС необхідно ввести блок зворотного зв'язку (Б33) (рис. 1, в). Завдяки загальнобіологічному ефекту акомодації, наприклад, при нейростимуляції чи дефібриляції, БТк змінює свої властивості. Проявом цього явища $є$ зміна ії електричного імпедансу та його складових $[10,11]$. Зворотний зв'язок дає можливість автоматично та швидко оптимізувати інтенсивність та форму сигналу впливу. За цим принципом побудовано електростимулятори типу “ЭЛИМАН” [10].

Особливість та складність метрологічного забезпечення БМЕА полягає у принциповій неможливості вибору еталонного БО. Тому оцінити вимірювання можна виключно моделюванням живої тканини, точніше, пасивних електричних властивостей біооб' єкта тканини, що змінюються за відомим законом відповідно до зміни фізіологічної (або морфологічної) характеристики, що вивчається.

Специфіка та складність обробки інформації часто становлять головну проблему під час розроблення апаратури та трактування отриманих результатів. Особливо це важливо в складних технічних засобах, наприклад, імпедансних томографах. У зв'язку із широким застосуванням у біомедичній апаратурі мікропроцесорної техніки суттєвого значення набуває блок БАПІ (рис. 1, г). Окрім стандартних функцій відображення інформації, реалізації інтерфейса користувача та керування іншими блоками БТС, він може виконувати функції блоків БЗВ та Б33, а також функції інтелектуальної обробки інформації, які неможливо реалізувати іншими засобами. Треба також враховувати можливість використання БМЕА як компонента КФС, який працює в режимі реального часу. В цьому випадку блок Оп - це інтерфейсний блок, що реалізує протоколи міжрівневого обміну інформацією в КФС.

Особливості проектування структури на рис. 1 , г розглядаємо на прикладі розроблення електроімпедансного методу та технічних засобів дослідження тканинного кліренсу рідин. Тканинний кліренс (ТК) - це “очищення" ділянки біологічної тканини від введеної до неї рідини (або газу). Спостереження ТК рідин належить до однієї з небагатьох можливостей отримання інформації про обмін речовин на капілярному рівні, тобто про мікроциркуляцію.

Дослідження динаміки ТК полягає у спостереженні за біофізичним параметром, зміна якого в часі відповідає динаміці процесу. В нашому випадку таким параметром є електричний імпеданс.

Головні переваги електроімпедансного методу порівняно з найпоширенішим методом Katy [14], полягають, насамперед, у відсутності радіоактивності, значному розширенні досліджуваних розчинів, можливості реєструвати динаміку процесу і багаторазових досліджень.

Виходячи 3 наведених обов'язкових операцій, синтезуємо оптимальну БТС, яка призначена для дослідження динаміки тканинного кліренса рідин. Тобто конкретизуємо склад елементів та їх взаємодію для структури БТС на рис. 1, г. (рис. 2) .

Розташування та зв'язки елементів структури насамперед пов'язані 3 тим, що метод $\epsilon$ інвазивним. У нашому випадку оптимальним $є$ використання ін'єкційної голки одночасно як вимірювального електрода. БЗВ у випадку, що розглядається, слугує блок введення рідини БВР.

Ключовим питанням розроблення технічних засобів дослідження тканинного кліренсу $є$ давач, який дає змогу одночасно вводити рідину у тканину та вимірювати тканинний імпеданс у місті введення. Таким вимогам відповідає давач 3 двома голчатими електродами, що закріплені на діелектричному тримачі. Робочий електрод порожнистий та приєднаний канюлею до блоку введення рідини. 


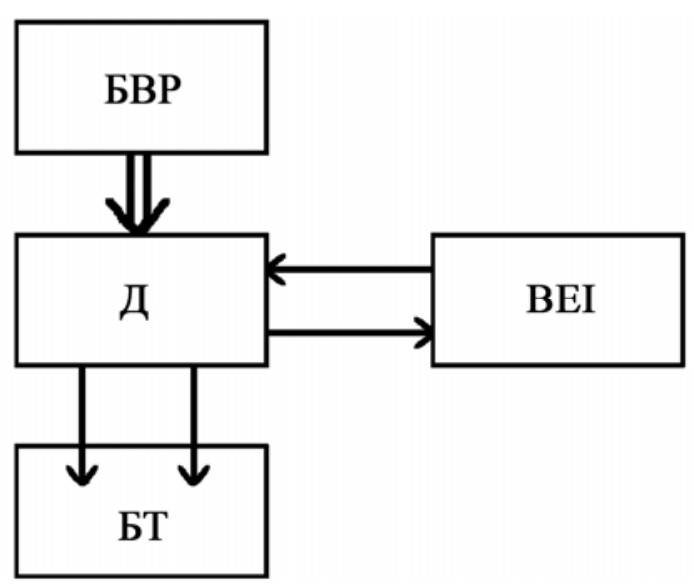

Рис. 2. БТС дослідження тканинного кліренсу рідин електроімпедансним методом:

БВР - блок введення рідин; Д - давач;

ВEI-вимірювач електричного імпедансу;

БТ - біологічна тканина

Для опису закономірностей тканинного кліренсу розроблено математичну модель, у якій об’єм біологічної тканини, що досліджується, представлений у вигляді сполучених між собою резервуарів (рис. 3).

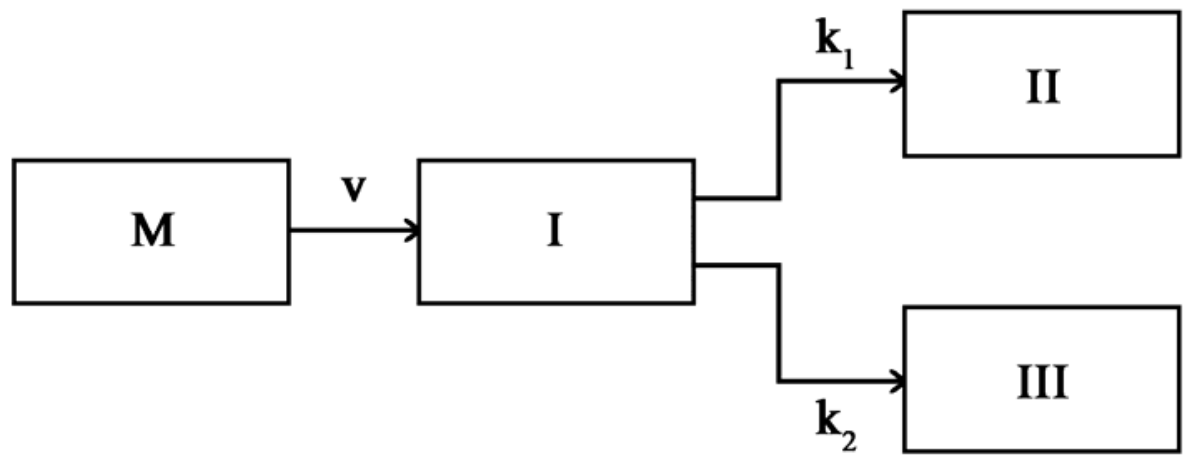

Рис. 3. Резервуари математичної моделі тканинного кліренсу рідин:

I - резервуар, щзо відповідає досліджуваному об'єму тканини, в який вводять рідину;

II - резервуар, щ⿻ відповідає кровоносним капілярам; III - резервуар,

щзо відповідає міжклітинній речовині, яка оточує введену рідину; $M$ - кількість рідини,

яку вводять у тканину (мл); v - швидкість введення рідини (мл/с);

$k_{l}$ - константа резорбиії рідини кровоносними капілярами $(1 / \mathrm{c})$;

$k_{2}$ - константа розсмоктування рідини в навколишню міжклітинну речовину $(1 / \mathrm{c})$

На відміну від моделі Каtу, розроблена модель враховує вплив на тканинний кліренс режиму введення рідини та розглядає дві фізіологічні складові кліренсу: капілярний кровоток та розповсюдження рідини у навколишню міжклітинну речовину.

Розглядаючи дві фази процесу - фазу введення рідини та безпосередньо вилучення рідини 3 тканини - отримано кінцеву систему рівнянь, що описують тканинний кліренс з урахуванням швидкості ведення та маси рідини.

За розробленою моделлю розраховано теоретичну залежність інформативного параметру кліренсу - часу напівкліренсу $\mathrm{T}_{50 \%}$ - від маси та швидкості введення рідини.

Для вибору робочого тиску введення рідини було експериментально визначено основні закономірності поглинання рідин біологічними тканинами. Визначали час поглинання 0,1 мл $0,9 \%$ розчину $\mathrm{NaCl}$ та дистильованої води у діапазоні тиску $15-45$ см водного стовпчика. 
За результатами аналізу розробленої математичної моделі та експериментальних даних було розраховано коефіцієнти резорбції та розсмоктування $0,9 \%$ розчину $\mathrm{NaCl}$ та дистильованої води.

Широкий вибір тестувальних розчинів, можливість визначення тканинного кліренсу газів відкривають широкі можливості використання електроімпедансного методу дослідження мікроциркуляторних процесів в експериментальній біології та медицині.

\section{Висновки}

Підхід до БМЕА як до складової БТС, виділення досліджуваного біофізичного параметра (у даному випадку біоелектричного імпедансу) в окрему структурну одиницю БТС дає змогу формулювати та розв' язати задачі проектування. Особливості БТС тісно пов'язані з послідовністю розроблення. Комплекс заходів проектування має починатися з синтезу відповідної БТС та аналізу взаємодії ії компонентів.

Особливості взаємодії між біологічною та технічною складовими системи задають перелік експериментальних, насамперед біофізичних, та теоретичних досліджень, що відбуваються паралельно до суто технічних етапів розроблення.

Особливість БМЕА з погляду метрології полягає у неможливості мати взірцевий БО. Визначити похибку апаратури можна виключно за допомогою моделювання біооб'єкта. Найбільша похибка БМЕА виникає у результаті взаємодії вимірювальних електродів і БО та у результаті перерахунку БФП у ФХ.

Використання БТС як компонента КФС висуває додаткові вимоги до організації протоколів обміну інформацією між рівнями КФС у реальному масштабі часу.

1. Абакумов В. Г., Рибін О. І., Сватош Й. Біомедичні сигнали. Генезис, обробка, моніторинг. K.: Hopa-nрuнт, 2001, 516 c. [Abakumov V. G., Ribin O. I., Svatos J. Biomedical signals. Genesis, processing, monitoring. K.: Nora-print, 2001, 516 p. (In Ukr.)] 2. Березко Л. О., Смердов А. А., Соколов C. Е. Можливості застосування біоелектроімпедансометрії для дослідження стану мікроциркуляції. Электроника и связь, 2011, № 2, c. 101-105. [Berezko L. O., Smerdov A. A., Sokolov S. E. Applicability bioelektroimpedansometriyi to study microcirculation. Electronics and Communication, 2011, № 2, pp. 101-105. (In Ukr.)] 3. Смердов А. А., Соколов С. С., Смердова T. А. Електроімпедансний метод дослідження мікрочиркуляиії у тварин. Вісник Полтавської державної аграрної академіï, 2010, № 1, c. 151-153. [Smerdov A. A., Sokolov S. E., Smerdova T. A. Electroimpedancemetric method for research of microcirculation in animal. News of Poltava State Agrarian Academy, 2010, № 1, pp. 151-153. (In Ukr.)]4. Смердов А. А., Соколов С. С., Смердова Т. А. Використання пасивних електричних параметрів біологічних тканин у сільському господарстві // Вісник Полтавської державної аграрної академії. - 2011. - № 1. - C. 142-147. [Smerdov A. A., Sokolov S. E., Smerdova T. A. The use of passive electrical parameters of biological tissues in agriculture. News of Poltava State Agrarian Academy, 2011, № 1, pp. 142-147. (In Ukr.)]5. Ахутин В. М. Бионические аспекты синтеза биотехнических систем. В сб.: Информационные материаль:: кибернетика. - М.: Сов. радио, 1976. № 4, c. 92-97. [Akhutin V. M.. Bionic aspects of the synthesis of biotechnical systems. In: Information materials: cybernetics. M.: Sov. radio, 1976, pp. 92-97. (In Russ.)]6. Джонс Дж. К. Методы проектирования. М.: Мup, 1986, 326 c. [Jones J. C. Design methods. M.: Mir, 1986, 326 p. (In Russ.)] 7. Беркутов А. М., Жулев В. И., Кураев Г. А., Прошин Е. М. Системы комплексной электромагнитотерапии. М.: Лаборатория Базовых Знаний, 2006, 376 c. [Berkutov A. M., Ghulev V. J., Kuraev G. A., Proshin E. M. Systems of complex electromagnet therapeutics. M.: Laboratory of base knowledge, 2000, 376 p. (In Russ.)]8. Смердов A. A., Сторчун Є. В. Біомедичні вимірювальні перетворювачі. Львів: Кальварія, 1997, 112 c. [Smerdov A. A., Storchun E. V. Biomedical measuring sensors. Lviv: Kalvariya, 1997, 112 p. (In Ukr.)]9. Мустецов Н. П., Белецкий Н. И., Катрич В. А. Медицинские электронные системы. - Харьков: ХНУ им. В. Н. Каразина, 2008, 248 с. [Mustetsov N. 
P., Bielecki N. I., Katrych V. A. Medical Electronic Systems. Kharkov: KNU them. Karazin, 2008, 248 p. (In Russ.)]10. Sokolov S. Application of Bioimpedancemetry Method for Analysis of Microcirculatory Parameters. International Conference "Modern Problems of Radio Engineering, Telecommunications and Computer Science”, Lviv Polytechnic National University, 2010, p. 138.11. Соколов C. E. Основныле свойства биотехнических систем. Матеріали ХІІ Міжнародної науково-практичної конференцї “Сучасні інформачійні та електронні технологіï”, Одесcа, 2011, c. 340. [Sokolov S. E. Main properties of Biotechnical Systems. Proceedings of the XII International Scientific Conference "Modern information and electronic technologies”, Odessa, 2011, p. 340. (In Russ.)] 12. Berezko L., Sokolov S. The systems approach to the development of electronic biomedical equipment. Advanced Computer Systems and Networks: Design and Application, Proceedings of the 6-th International Conference ACSN-2013, Lviv, pp. 38-40.13. Соколов C. Е. Биофизика в биотехнических системах. Материалы II Международной научно-технической конференции “Современные проблемы физики, химии и биологии. ФизХимБио-2013”, Севастополь, 2013, c. 133-134. [Sokolov S. E. Biophysics in biotechnical technologies and systems. Materials of II International Science-Technical Conference "Modern issues in physics, chemistry and biology. PhysChemBio-2013”, , Sevastopol, 2013, pp. 133-134. (In Russ.)]14. Kety S. S. Measurement of regional circulation by the local clearance of radioactive sodium. American Heart Journal, 1949, № 3, pp. 321-328. 15. Мельник А.О. Кіберфізичні системи: проблеми створення та напрями розвитку // Вісник Наи. ун-ту “Львівська політехніка”. - 2014. - № 806: Комп’ютерні системи та мережі. - C. 154-161. 16. Anatoliy Melnik. Cyber-physical systems multilayer platform and research framework. Advances in cyber-physical systems. Volume1.Number1,2016, pp.1-6. 